\title{
Isolation, Culture, and Differentiation of Blastema Cells from the Regenerating Caudal Fin of Zebrafish
}

\author{
Parameswaran Vijayakumar ${ }^{1,2, *}$, M. Leonor Cancela ${ }^{2,3} \mathbb{C}$ and Vincent Laizé ${ }^{2}$ (D) \\ 1 Centre for Ocean Research, Sathyabama Institute of Science and Technology, Jeppiaar Nagar, Rajiv Gandhi \\ Salai, Chennai, Tamil Nadu 600119, India \\ 2 Centre of Marine Sciences (CCMAR), University of Algarve, Campus de Gambelas, 8005-139 Faro, Portugal; \\ lcancela@ualg.pt (M.L.C.); vlaize@ualg.pt (V.L.) \\ 3 Department of Biomedical Sciences and Medicine (DCBM) and Algarve Biomedical Center (ABC), \\ University of Algarve, Campus de Gambelas, 8005-139 Faro, Portugal \\ * Correspondence: vijayparamesh@gmail.com
}

Received: 3 July 2019; Accepted: 19 January 2020; Published: 30 January 2020

\begin{abstract}
The caudal fin of teleost fish has become an excellent system for investigating the mechanisms of epimorphic regeneration. Upon amputation of the caudal fin, a mass of undifferentiated cells, called blastema, proliferate beneath the wound-epidermis and differentiate into various cell types to faithfully restore the missing fin structures. Here we describe a protocol that can be used to isolate and culture blastema cells from zebrafish. Primary cultures were initiated from $36 \mathrm{~h}$ post-amputation (hpa) blastema and optimal cell growth was achieved using L-15 medium supplemented with 5\% fetal bovine serum in plates either coated with fibronectin or uncoated. After seeding, zebrafish blastema cells formed a uniform culture and exhibited polygonal shapes with prominent nucleus, while various cell types were also observed after few days in culture indicating cell differentiation. Upon treatment with all-trans retinoic acid, zebrafish blastema cells differentiated into neuron-like and oligodendritic-like cells. Immunocytochemistry data also revealed the presence of mesenchymal and neuronal cells. The availability of blastema cell cultures could contribute to a better understanding of epimorphic regeneration by providing a mean to investigate the mechanisms underlying blastema cell differentiation. Furthermore, this protocol is simple, rapid, and cost-efficient, and can be virtually applied to the development of any fish blastema cell culture.
\end{abstract}

Keywords: primary cell culture; blastema; zebrafish; fin regeneration; cell differentiation

\section{Introduction}

Due to its remarkable simplicity and accessibility, the caudal fin of teleost fish has become an excellent system for investigating the cellular and molecular mechanisms of epimorphic regeneration, i.e., the complete reformation of missing tissues (reviewed by [1-5]). Upon amputation of caudal fin tissues (i.e., bony rays covered with a thin epidermis, nerves, blood vessels, and connective tissue), a thick wound epidermis forms rapidly at the amputation plane, while a mass of undifferentiated cells, called blastema, proliferate beneath the wound epidermis [6]. It has been proposed that blastema is formed by cells that de-differentiate but remain lineage committed [7-9]. Blastema cells will contribute to various cell types-e.g., osteoblasts, vasculature, melanocytes, and epidermal cells-to faithfully restore missing fin structures [10-13] through molecular and genetic processes that have been approached in several studies [14-17]. Recently, Tu and Johnson demonstrated that blastema cells do not differentiate into cell lineages that were not already present in the caudal fin tissues [9].

Full regeneration is usually achieved after 10-15 days depending on the species, the level of amputation, and culture conditions. Protocols to prepare zebrafish primary cell cultures have 
been established recently to study the structural and functional properties of cardiomyocytes [18], neurogenesis [19], and mechanisms underlying inhibition of neural regeneration in vitro [20], and while several cell lines have been developed from the caudal fin in zebrafish [21,22] and other fish species [23-26], none have been reported for the blastema yet. In this study, a protocol was established to isolate blastema cells from the zebrafish Danio rerio (Hamilton 1822) and to successfully initiate primary cell cultures. It is expected that the availability of such in vitro cell systems will contribute to a better understanding of epimorphic regeneration by providing a means to investigate mechanisms underlying blastema cell differentiation, while also complementing the work performed in vivo.

\section{Results and Discussion}

The development of primary cultures of blastema cells (see Figure 1A-C and detailed protocol in the Materials and Methods section) opens the possibility to investigate in vitro the cellular and molecular mechanisms underlying epimorphic regeneration of the caudal fin of fish. Zebrafish cells obtained after enzymatic dissociation of regenerating fin tissues adhered rapidly on the substratum at $28{ }^{\circ} \mathrm{C}$ (Figure 1D), proliferated continuously for about $48 \mathrm{~h}$, and could be maintained for 1 or 2 passages. Longer survival times were reported for salamander limb blastema cells (up to 30 days in culture; [27]). The possibility of the zebrafish cells being in a committed stage and less prone to active proliferation after 3 days of culture conditions could explain a shorter survival time, although the lack of specific growth factors are also conceivable. In this regard, culture medium could be supplemented with (1) conditioned medium obtained from zebrafish ES cells, (2) zebrafish embryo extract, (3) fish serum (instead of bovine serum) prepared from farmed fishes, e.g., Atlantic salmon, trout, tilapia, and gilthead seabream [28,29], or (4) growth factors such as Wnt, TGF- $\beta$, IGF-1, bFGF, or LIF [30-34]. To extend their lifetime, blastema cells could also be cultured in a collagenous gel [35] or as organotypic slice culture [36]. The use of a feeder layer to grow zebrafish blastema cells could be tested as it was shown to be critical to the growth and maintenance of undifferentiated state of mouse embryonic stem (ES) cells [37].

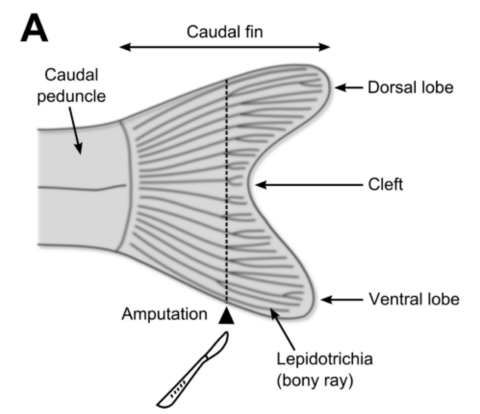

D

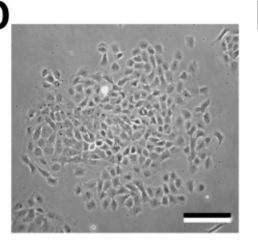

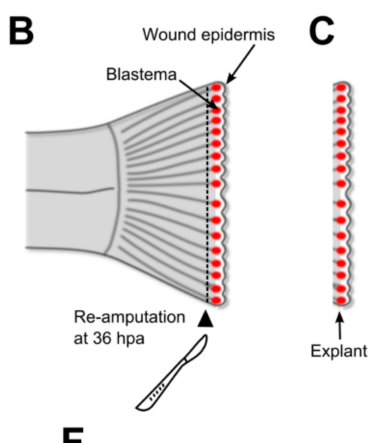
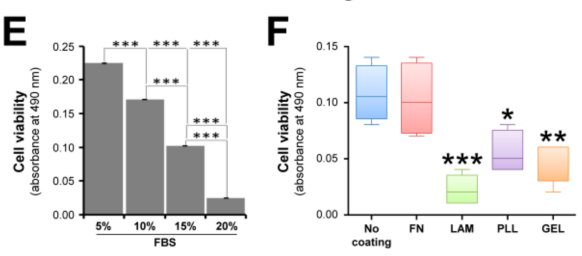

Figure 1. Schematic diagram for caudal fin amputation, blastema collection, and blastema cell culture. (A) Amputation of the caudal fin; $(\mathbf{B}, \mathbf{C})$ re-amputation procedures towards blastema collection. Dotted lines indicate amputation and re-amputation planes. Blastema is indicated in red; (D) phase-contrast micrographs of zebrafish blastema cell cultures at $72 \mathrm{~h}$ post-seeding; (E) viability of blastema cells cultured in medium supplemented with different concentrations of FBS; (F) viability of blastema cells cultured on surfaces coated with different molecules. In $(\mathbf{E}, \mathbf{F})$, cell viability was measured $72 \mathrm{~h}$ post-seeding and asterisks indicate values significantly different through one-way ANOVA followed by Tukey's (E) or Dunnett's (F) multiple comparison test $\left({ }^{* * *} p<0.001,{ }^{* *} p<0.01\right.$, and $\left.{ }^{*} p<0.05 ; n=6\right)$. FN, fibronectin; LAM, laminin; PLL, poly-L-lysine; GEL, gelatin. Scale bar in (D) is $100 \mu \mathrm{m}$. 
Approximately 3-3.5 $\times 10^{4}$ cells were recovered per blastema with a viability higher than $90 \%$. Blastema cells were routinely cultured in L-15 medium supplemented with 5\% FBS after a reduced proliferation rate was observed in cultures supplemented with $10 \%, 15 \%$, and $20 \%$ of serum (Figure 1E), an observation in agreement with the data published by Kumar and Godwin [27] showing the inability of salamander limb blastema cells to survive in culture media containing high levels of bovine serum. Thus, salamander blastema cells were cultured in medium containing $<2 \%$ of FBS (e.g., in serum-free medium or medium with $0.5-1 \%$ serum) to reduce cell death. Whether zebrafish blastema cells can be maintained in medium containing less than $5 \%$ of FBS should be further tested. The morphology of zebrafish blastema cells cultured in 5\% FBS was polygonal with a prominent nucleus and maintained over time. (Figure S1). Coating the surface of cell culture dishes with extracellular matrix molecules, e.g., fibronectin, laminin, poly-L-lysine, and gelatin, can promote cell attachment, growth, spreading, and differentiation [38]. While fibronectin slightly stimulated the viability of zebrafish blastemal cells, laminin, poly-L-lysine, and gelatin triggered an anti-proliferative effect. It appeared that fin blastema cell attachment or growth was best in the absence of any coating (Figure 1F). No deposition of mineral was observed in blastema cell cultures treated with mineralogenic cocktail (Figure S2), although the absence of ECM mineralization may be related to the short treatment.

Although Tu and Johnson reported that blastema cells do not differentiate into cell lineages that are not already present in the caudal fin tissues [19], new cell types, i.e., spindle-shaped, oligodendritic-like, neuron-like cells, were observed in blastema cell cultures after 3 days in culture (Figure 2A-G). The presence of these new types of cells may depend on culture conditions e.g., the absence of a particular cell substrate or growth factor, the presence of fetal bovine serum, or the temperature and the osmolarity of the culture medium. As for murine embryonic stem (ES) cells that require a feeder layer or leukemia inhibitory factor to maintain an undifferentiated state [34,39], blastema cells may need particular culture conditions to maintain their lineage commitment. In this regard, organotypic slice culture (OSC) of blastema explants may be tried in the future to maintain the original tissue architecture. The treatment of zebrafish blastema cells with all-trans retinoic acid (RA) also triggered the appearance of neuron-like and oligodendritic-like cells (Figure 2H,I), in agreement with a recent study reporting the differentiation of rabbit pinna-derived blastema cells into neuronal cells upon RA treatment [40]. Similar changes in cell phenotype were also found in human, Japanese medaka, and gilthead seabream cells [41-43]. Vitamin A (including compounds such as retinol and $\mathrm{RA}$ ) is a signaling molecule that plays key roles in vertebrate pattern formation both in developing and regenerating tissues and to the differentiation of many types of cells [44-49]. The production of endogenous RA from retinol is essential for the regeneration of zebrafish fin [50] and RA signaling is enhanced in the stump mesenchyme within the first few hours after fin amputation [51]. The effect of exogenous administration of RA is however controversial. It has been shown to either impair fin regeneration by blocking blastema formation $[44,52,53]$ or to enhance RA signaling and positively influence fin regeneration [51]. RA is not only a potent and effective inducer of embryonic stem cell differentiation [54] but also of zebrafish blastema cell differentiation (this study). 


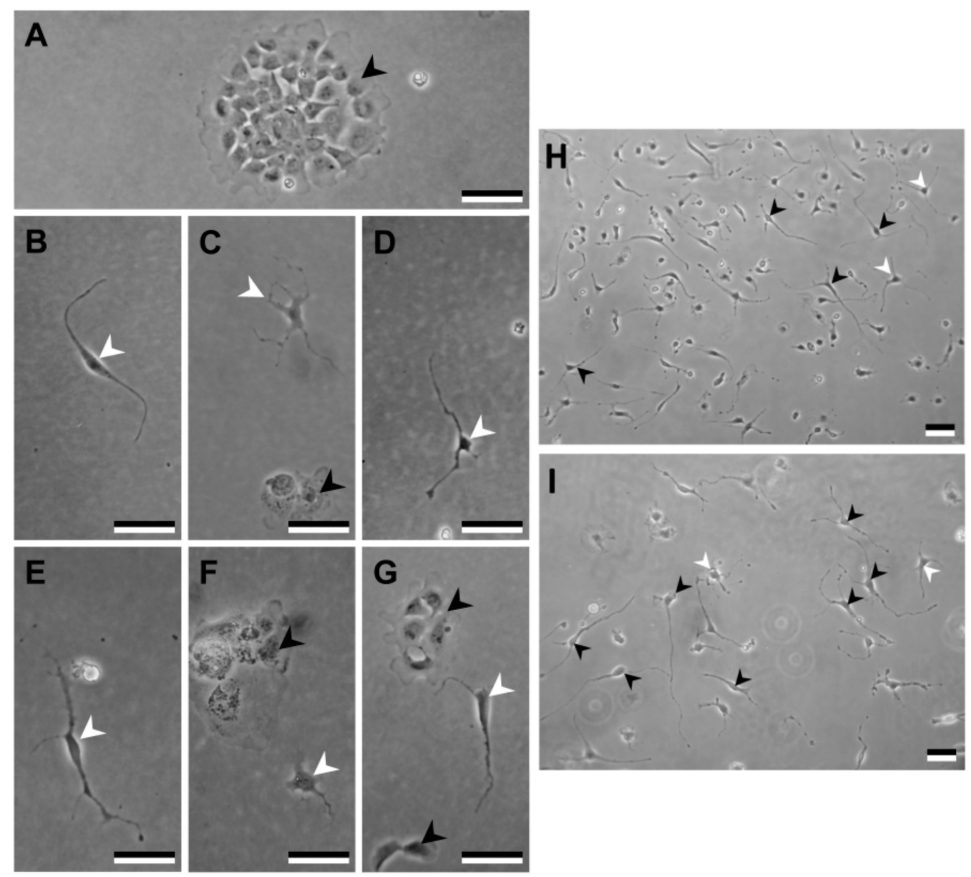

Figure 2. Spontaneous differentiation of zebrafish blastema cells after 5 days in culture. (A) Homogenous progenitor blastema cells showing polygonal cells with prominent nuclei and sparse cytoplasm. (B-G) Differentiated cells exhibiting a spindle-like (B), an oligodendritic-like (C), and a neuron-like (D-G) phenotype. Black and white arrowheads show progenitor blastema cells and differentiated cells, respectively. (H,I) Phase-contrast micrographs of zebrafish blastema cells exposed to $0.5 \mu \mathrm{m}$ all-trans retinoic acid at day 7. Neuron-like (black arrowheads) and oligodendritic-like (white arrowheads) cells at 7 days of treatment. Scale bar is $50 \mu \mathrm{m}$ in (A-G) and (I), and $100 \mu \mathrm{m}$ in (H).

Differentiation of blastema cells was evaluated days 1 and 5 by immunocytochemistry using lineage specific markers (Figure 3). The number of cells positive for Oc1 (osteoblast marker), Zns5 (scleroblast/osteoblast marker), and Zn12 (a neuronal cell surface marker) markedly increased from day 1 to day 5 (Figure 3A-O). There was also a strong decrease in the number of cells positive for Ssea1 (a marker for undifferentiated cells in rodents). It is worth mentioning that Ssea1 monoclonal antibodies efficiently functioned when used in zebrafish blastema cells, as already seen in zebrafish blastula cells [55] and zebrafish transient embryonic stem cells [56]. The number of cells positive for PHH3 (a marker for proliferation) was also reduced at the same time points (Figure 3P-Y), indicating the potential of blastema cells (at least a large part of the cell population) to differentiate into several cell types, in particular osteoblasts and neurons, and therefore their suitability to study molecular and cellular mechanisms involved in fin regeneration, in particular de novo bone and nerve formation. Our results also demonstrated the suitability of this protocol to develop blastema cell cultures. This protocol has been successfully validated and also applied to develop blastema primary cell cultures from other teleost like gilthead seabream and mosquitofish (data not shown). The advantage of this protocol is that it is simple, rapid, and cost efficient, and can be virtually applied in the development of any fin blastema cell cultures. Our future work will aim to evaluate means to extend the lifetime of blastema cell primary cultures, e.g., the use of a feeder layer or some specialized medium to sustain cell growth, or to transform primary cell cultures into continuous cell lines. 


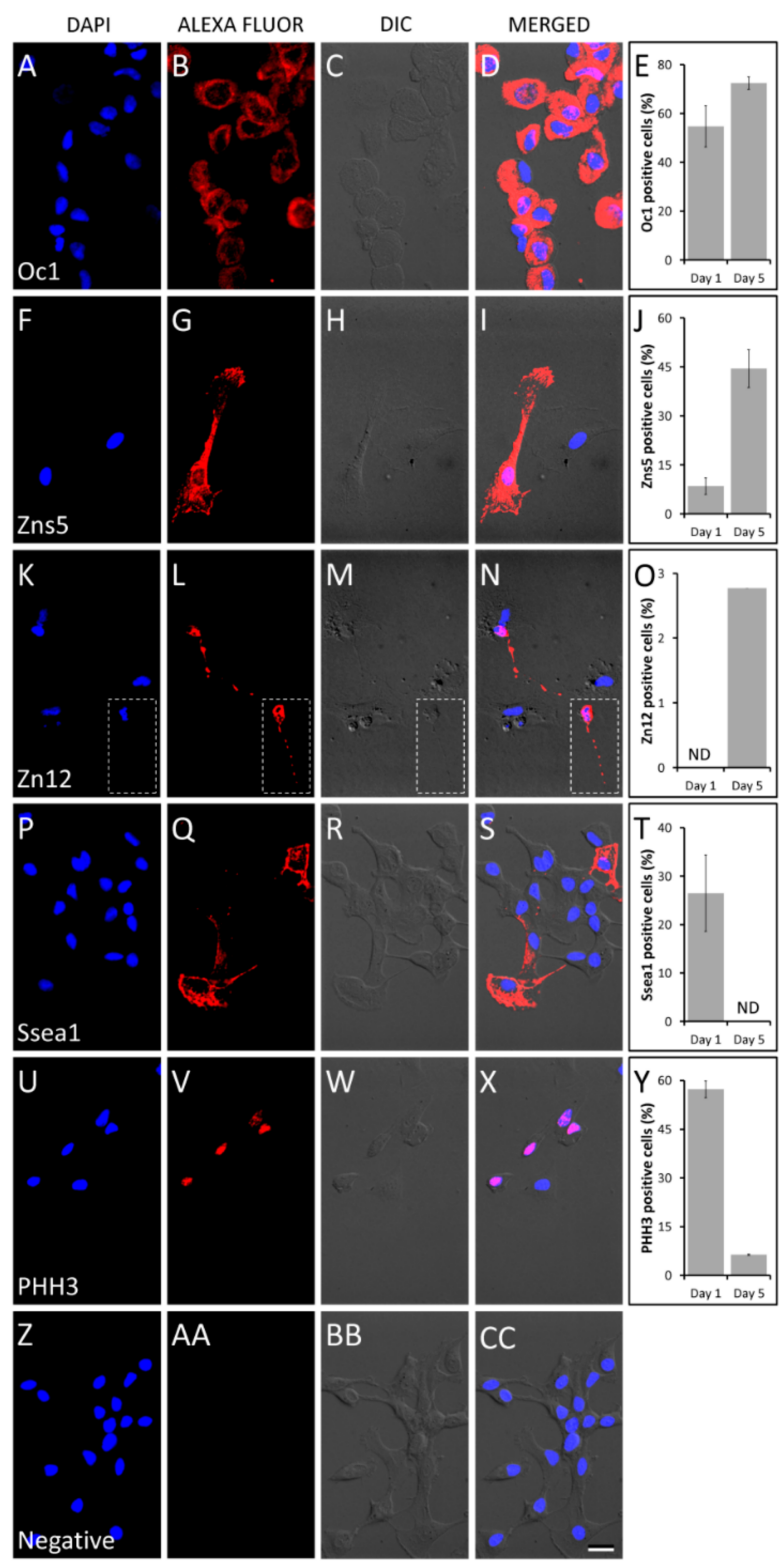

Figure 3. Differentiation of zebrafish blastema cells confirmed by immunofluorescence labeling at day 5 (except for Ssea1 at day 1). Zebrafish blastema cells immunolabeled with the osteoblast marker Osteocalcin 1/Oc1 (A-D), the scleroblast marker Zns5 (F-I), the neuronal cell surface marker Zn12 (K-N; inserts illustrate a neuron-like cell), the stage-specific embryonic antigen Ssea1 (P-S), and the proliferation marker PHH3 (U-X). For each marker, picture sequence is as follows: DAPI labeling, ALEXA Fluor 594 labeling, differential interference contrast (DIC) image and merge image; percentages of cells positive for each marker at days 1 and 5 of cell culture were determined from manual counting and are presented as mean \pm standard deviation calculated from three different coverslips $(\mathbf{E}, \mathbf{J}, \mathbf{O}, \mathbf{T}, \mathbf{Y})$. Negative control (Z-CC). ND, not detected. Scale bar is $10 \mu \mathrm{m}$.

\section{Materials and Methods}

\subsection{Fish Maintenance}

Young adult zebrafish (AB line) of about 3-4 months were maintained in 10-L plastic tanks with recirculating fresh water at $28^{\circ} \mathrm{C}$ (ZebTEC housing system from Tecniplast, Buguggiate, Italy) and fed twice a day with dry food (Tetramin flake C) and live Artemia nauplii (INVE Aquaculture, Dendermonde, Belgium). 


\subsection{Primary Blastema Cells Isolation and Culture}

The detailed protocol to isolate and obtain primary blastema cells is as follows:

\subsubsection{Amputation of the Caudal Fin}

Clean the working area with 70\% ethanol and autoclave all the dissection instruments.

1. Anesthetize the animals by exposing them to tricaine methanesulfonate (MS-222; $0.01 \%(w / v)$ in fish water; Sigma-Aldrich, St. Louis, MO, USA) for 4-6 min. Animals are anesthetized in batches of five fishes.

2. Using blunt-end forceps, transfer anesthetized fish onto an inverted Petri dish (sterile, bacterial) placed on the stage of a stereomicroscope (e.g., MZ6 from Leica Microsystems, Wetzlar, Germany) and carefully deploy and flatten the caudal fin.

3. Using a sterile scalpel (scalpel No. 4 and blade No. 24), amputate the caudal fin in two segments ahead of the cleft (see Figure 1A). Clean cut is achieved by positioning the blade tip on the Petri dish and by sectioning the fin in a single downward movement.

4. Transfer fish with amputated fins back to their aquarium or tank.

5. Repeat Steps $2-4$ for the remaining animals.

6. Maintain the animals in normal culture conditions until re-amputation.

\subsubsection{Blastema Collection}

Clean the working area with $70 \%$ ethanol and autoclave all the dissection instruments; coat cell culture dishes with appropriate molecules according to manufacturer's instructions.

7. At $36 \mathrm{~h}$ post-amputation (hpa), repeat Steps 1 and 2 for all animals.

8. Using a sterile scalpel, re-amputate the caudal fin one segment ahead of the first amputation plane (see Figure 1B). See Step 3 for making clean cuts.

9. Using sharpened forceps, collect the fin fragment containing the whole blastema (see Figure 1C) and transfer it into a Petri dish containing $3 \mathrm{~mL}$ of Leibovitz's L-15 culture medium (Invitrogen, Carlsbad, CA, USA) supplemented with $5 \times$ antibiotics (100× solution containing 10,000 units of penicillin, and 10,000 $\mu \mathrm{g}$ of streptomycin per $\mathrm{mL}$; Invitrogen) and $1 \times$ fungizone (100× solution containing $250 \mu \mathrm{g}$ of amphotericin B per mL; Invitrogen) and allow it to bath for $15 \mathrm{~min}$ to avoid bacterial contamination.

10. Repeat Steps 8 and 9 for the remaining animals.

11. Transfer the blastemas into a sterile $1.5-\mathrm{mL}$ microcentrifuge tube containing $1 \mathrm{~mL}$ of collagenase solution $(0.125 \%(w / v)$ in PBS; Invitrogen).

12. Gently dissociate the blastemas by pipetting up and down (approximately 15 times using a $1000 \mu \mathrm{L}$ micropipette) and place the tube in a rotary shaker for $10 \mathrm{~min}$ at room temperature (approximately $24-25^{\circ} \mathrm{C}$ ).

13. Centrifuge the tube for $3 \mathrm{~min}$ at $972 \times g$ at $25^{\circ} \mathrm{C}$ and gently discard the supernatant.

14. Add $0.5 \mathrm{~mL}$ of trypsin-EDTA solution ( $0.25 \%$ trypsin (Invitrogen) and $1.1 \mathrm{mM}$ EDTA in phosphate-buffered saline (PBS, $1 \times$, sterile); $\mathrm{pH} 7.4$ ) and gently pipette up and down (using a $1000 \mu \mathrm{L}$ micropipette) to resuspend the cells and then place the tube in a rotary shaker for 3-5 $\mathrm{min}$ at $25^{\circ} \mathrm{C}$. Almost all the blastemas are dissociated during collagenase and trypsin treatment.

15. Repeat Step 13 and gently resuspend the cells in $1 \mathrm{~mL}$ of L-15 medium.

16. Repeat Step 13 and gently resuspend the cells in $1 \mathrm{~mL}$ of $\mathrm{L}-15$ medium supplemented with $5 \%$ fetal bovine serum (FBS; Sigma-Aldrich), $1 \times$ antibiotics, and $0.2 \times$ fungizone.

17. Count cells using a Neubauer counting chamber (BLAUBRAND) and seed $1.5 \times 10^{3}$ cells per well in a 96-well dish (Nunc, Roskilde, Denmark) coated with laminin, gelatin, fibronectin, or poly-L-lysine and $1 \times 10^{4}$ cells per well in a 24-well dish (Nunc) for cell culture. 
18. Incubate enzymatically dissociated cell cultures in a $28^{\circ} \mathrm{C}$ cell incubator (e.g., Galaxy $170 \mathrm{~S}$ from New Brunswick Scientific, Enfield, CT, USA).

\subsubsection{Maintenance of Primary Cell Cultures}

19. Observe daily the growth of primary cell cultures under an inverted microscope (e.g., Axiovert 25 from Zeiss, Oberkochen, Germany).

20. Renew culture medium every 3 days.

21. At confluence, cells are detached/dissociated with trypsin-EDTA and then split 1:2.

\subsection{ECM Coating of Tissue Culture Dishes}

Stock solution of poly-L-lysine at $0.1 \mathrm{mg} / \mathrm{mL}$ was prepared using sterile water. Then, $100-200 \mu \mathrm{L}$ of this solution was aseptically added in a well of 24-well plate, rocked gently for 5 min to ensure a homogenous coating of the well. The solution was removed and wells were rinsed thoroughly with sterile water and allowed to dry for $2 \mathrm{~h}$ in the biological safety cabinet. The same procedure was followed for laminin $(0.1 \mathrm{mg} / \mathrm{mL})$ and gelatin $(1 \mathrm{mg} / \mathrm{mL})$ coated plates although incubation was carried out at $37^{\circ} \mathrm{C}$ and washes done with PBS. For fibronectin $(0.05 \mathrm{mg} / \mathrm{mL})$, plates were air dried for $1 \mathrm{~h}$ at $25^{\circ} \mathrm{C}$, then excess of fibronectin was removed and the culture dish rinsed with PBS.

\subsection{Cell Viability}

Viability of blastema cells was subsequently determined in media supplemented with different FBS concentrations and in dishes coated with different extracellular matrix (ECM) molecules i.e., fibronectin, laminin, poly-L-lysine, and gelatin (all from Sigma-Aldrich) using XTT Cell Proliferation kit (AppliChem, A8088) according to manufacturer's instructions. Briefly, the cells were seeded at $1.5 \times 10^{3}$ cells/well in 96-well plates. At appropriate times, cells were incubated for $3 \mathrm{~h}$ with $50 \mu \mathrm{L}$ of reagent mixture in $100 \mu \mathrm{L}$ medium then cell viability was determined from absorbance at $490 \mathrm{~nm}$.

\subsection{Extracellular Matrix mineralization and Acridine Orange Staining}

Blastema cells were seeded at $1.0 \times 10^{5}$ cells/well in six-well plates. ECM mineralization was induced by supplementing the culture medium with a mineralogenic cocktail composed of $10 \mathrm{mM}$ $\beta$-glycerophosphate, $4 \mathrm{mM}$ calcium chloride, and $50 \mu \mathrm{g} / \mathrm{mL}$ of L-ascorbic acid. After 3 and 5 days of treatment, ECM mineralization was assessed through alizarin red $\mathrm{S}$ staining (AR-S, $40 \mathrm{mM}$ at $\mathrm{pH}$ 4.2; Sigma-Aldrich) and nucleic acids were revealed through acridine orange staining ( $100 \mu \mathrm{g} / \mathrm{mL}$ in PBS). Stained cells were visualized under an inverted fluorescence light microscope.

\subsection{Cell Differentiation}

Blastema cells were seeded at $1.5 \times 10^{3}$ cells/well in 96-well plates. After $24 \mathrm{~h}$, medium was renewed and supplemented with $0.5 \mu \mathrm{M}$ all-trans retinoic acid (RA; Sigma-Aldrich, R2625) or with $0.1 \%$ dimethyl sulfoxide (DMSO; Sigma-Aldrich, D2650), the vehicle control. Morphological changes in cells were examined daily under an inverted microscope equipped with phase contrast.

\subsection{Immunofluorescence Staining}

For immunophenotyping, blastema cells grown on 12-mm glass coverslips (VWR, West Chester, PA, USA) for 1 day, and 5 days after seeding were briefly fixed for $10 \mathrm{~min}$ with $100 \%$ ice-cold methanol (Merck, Darmstadt, Germany), washed with PBS, permeabilized with $0.1 \%$ Triton X-100 (Sigma-Aldrich) for $5 \mathrm{~min}$, and blocked in PBS containing 1\% bovine serum albumin (BSA; VWR). Purified mouse monoclonal antibodies against Zns5 (ZIRC, 090511), Ssea1, and Zn-12 (Developmental Studies Hybridoma Bank, MC-480 and zn-12), and purified rabbit polyclonal antibodies against Oc1 [57] and PHH3 (Cell Signaling Technology, 9701), were diluted 1:200 in PBS with 1\% BSA and directly added to the fixed cells at $25^{\circ} \mathrm{C}$ for $2 \mathrm{~h}$. Cells were washed with 1:10 dilution of blocking 
buffer in PBS then incubated with secondary antibodies Alexa Fluor 594 (goat anti-mouse IgG A-11005; Invitrogen) or Alexa Fluor 488 (goat anti-rabbit IgG A-11008; Invitrogen) diluted 1:1000 in the same solution as the primary antibody for $45 \mathrm{~min}$ at room temperature in the dark. Cells were washed thrice with PBS and then incubated with DAPI (Merck) for $5 \mathrm{~min}$. The cells were again washed several times with PBS and mounted in microscope slides (VWR) using Mowiol (Sigma-Aldrich), then observed using an Axioimager Z2 fluorescence microscope equipped with an Axiocam camera (Zeiss).

\section{Conclusions}

In this article we described the protocol for the successful culture of blastema cells collected from regenerating caudal fin of zebrafish. Cultured blastema cells spontaneously differentiated into different cell types, in particular those related to bone formation. The availability of such in vitro cell system represents a promising tool for investigating mechanisms of blastema cell differentiation during fin regeneration.

Supplementary Materials: The following are available online at http://www.mdpi.com/2410-3888/5/1/6/s1. Figure S1. Phase-contrast $(\mathbf{A}, \mathbf{C}, \mathbf{E})$ and fluorescence $(\mathbf{B}, \mathbf{D}, \mathbf{F})$ micrographs of acridine orange stained blastema cells cultured for $24 \mathrm{~h}(\mathbf{A}, \mathbf{B}), 72 \mathrm{~h}(\mathbf{C}, \mathbf{D})$ and $120 \mathrm{~h}(\mathbf{E}, \mathbf{F})$ in medium supplemented with 5\% FBS. Bar is $200 \mu \mathrm{m}$, Figure S2. Phase-contrast micrographs of alizarin red S-stained blastema cells treated for 3 days (A) and 5 days (B) with the mineralogenic cocktail to induce extracellular matrix mineralization.

Author Contributions: P.V., V.L. and M.L.C. designed the experiments. P.V. and V.L. carried out the experiments. P.V., V.L. and M.L.C. interpreted the data. All authors wrote the manuscript. All authors have read and agreed to the published version of the manuscript.

Funding: This work was funded by the Portuguese Science and Technology Foundation (FCT) through FISHCELL (PTDC/MAR/105313/2008) and AQUATOX (PTDC/MAR/112992/2009) research projects and by the European Community (EC) through ASSEMBLE (FP7/227799) research project. It was also funded by FCT through UID/Multi/04326/2019 project. P.V. was supported by a post-doctoral grant (SFRH/BPD/39189/2007) from the FCT.

Acknowledgments: We would like to thank the Department of Biomedical Sciences and Medicine at the University of Algarve for using the microscopy facility to acquire fluorescence images. We also thank Paulo J. Gavaia for his assistance in fish care.

Conflicts of Interest: The authors declare no competing or financial interests.

Compliance with Ethical Standards: Animal handling and experimentation was performed by qualified operators legally accredited by the Portuguese Direção Geral de Alimentação e Veterinária (DGAV) and following the EU and Portuguese legislation for animal experimentation and welfare (Directive 86/609/CEE and 2010/63/EU, Portaria 1005/92, 466/95 and 1131/97). Experimental procedures were performed under authorization (0421/000/000) from the DGAV, complying with the decreto de lei 113/2013 de 7 de Agosto, from the Portuguese legislation.

\section{References}

1. Akimenko, M.-A.; Mari-Beffa, M.; Becerra, J.; Géraudie, J. Old questions, new tools, and some answers to the mystery of fin regeneration. Dev. Dyn. 2003, 226, 190-201. [CrossRef] [PubMed]

2. Poss, K.D.; Keating, M.T.; Nechiporuk, A. Tales of regeneration in zebrafish. Dev. Dyn. 2003, 226, $202-210$. [CrossRef] [PubMed]

3. Nakatani, Y.; Kawakami, A.; Kudo, A. Cellular and molecular processes of regeneration, with special emphasis on fish fins. Dev. Growth Differ. 2007, 49, 145-154. [CrossRef] [PubMed]

4. Yoshinari, N.; Kawakami, A. Mature and juvenile tissue models of regeneration in small fish species. Biol. Bull. 2011, 221, 62-78. [CrossRef] [PubMed]

5. Gemberling, M.; Bailey, T.J.; Hyde, D.R.; Poss, K.D. The zebrafish as a model for complex tissue regeneration. Trends Genet. 2013, 29, 611-620. [CrossRef] [PubMed]

6. Akimenko, M.-A.; Smith, A. Paired fin repair and regeneration. In Fins into Limbs: Evolution, Development, and Transformation; Hall, B.K., Ed.; University of Chicago Press: Chicago, IL, USA, 2007; pp. 152-162.

7. Knof, F.; Hammond, C.; Chekuru, A.; Kurth, T.; Hans, S.; Weber, C.W.; Mahatama, G.; Fisher, S.; Brand, M.; Schulte-Merker, S.; et al. Bone regenerates via dedifferentiation of osteoblasts in the zebrafish fin. Dev. Cell 2011, 20, 713-724. [CrossRef] 
8. Sousa, S.; Afonso, N.; Bensimon-Brito, A.; Fonseca, M.; Simões, M.; Leon, J.; Roehl, H.; Cancela, M.L.; Jacinto, A. Differentiated skeletal cells contribute to blastema formation during zebrafish fin regeneration. Development 2011, 138, 3897-3905. [CrossRef]

9. Tu, S.; Johnson, S.L. Fate restriction in the growing and regenerating zebrafish fin. Dev. Cell 2011, 20, 725-732. [CrossRef]

10. Stoick-Cooper, C.L.; Moon, R.T.; Weidinger, G. Advances in signaling in vertebrate regeneration as a prelude to regenerative medicine. Genes Dev. 2007, 21, 1292-1315. [CrossRef]

11. Wehner, D.; Weidinger, G. Signaling networks organizing regenerative growth of the zebrafish fin. Trends Genet. 2015, 31, 336-343. [CrossRef]

12. Pfefferli, C.; Jaźwińska, A. The art of fin regeneration in zebrafish. Regeneration 2015, 19, 72-83. [CrossRef]

13. Bergen, D.J.M.; Kague, E.; Hammond, C.L. Zebrafish as an emerging model for osteoporosis: A primary testing platform for screening new osteo-active compounds. Front. Endocrinol. 2019, 10, 6. [CrossRef]

14. Whitehead, G.G.; Makino, S.; Lien, C.L.; Keating, M.T. fgf20 is essential for initiating zebrafish fin regeneration. Science 2005, 310, 1957-1960. [CrossRef] [PubMed]

15. Lee, Y.; Hami, D.; De Val, S.; Kagermeier-Schenk, B.; Wills, A.A.; Black, B.L.; Weidinger, G.; Poss, K.D. Maintenance of blastemal proliferation by functionally diverse epidermis in regenerating zebrafish fins. Dev. Biol. 2009, 331, 270-280. [CrossRef] [PubMed]

16. Yoshinari, N.; Ishida, T.; Kudo, A.; Kawakami, A. Gene expression and functional analysis of zebrafish larval fin fold regeneration. Dev. Biol. 2009, 325, 71-81. [CrossRef] [PubMed]

17. Singh, S.P.; Holdway, J.E.; Poss, K.D. Regeneration of amputated zebrafish fin rays from de novo osteoblasts. Dev. Cell 2012, 22, 879-886. [CrossRef]

18. Sander, V.; Suñe, G.; Jopling, C.; Morera, C.; Izpisua Belmonte, J.C. Isolation and in vitro culture of primary cardiomyocytes from adult zebrafish hearts. Nat. Protoc. 2013, 8, 800-809. [CrossRef]

19. Tapanes-Castillo, A.; Shabazz, F.S.; Mboge, M.Y.; Vajn, K.; Oudega, M.; Plunkett, J.A. Characterization of a novel primary culture system of adult zebrafish brain stem cells. J. Neurosci. Methods 2014, 223, 11-19. [CrossRef]

20. Chen, Z.; Lee, H.; Henle, S.J.; Cheever, T.R.; Ekker, S.C.; Henley, J.R. Primary neuron culture for nerve growth and axon guidance studies in zebrafish (Danio rerio). PLoS ONE 2013, 8, e57539. [CrossRef]

21. Yan, C.H.; Chan, K.M. Characterization of zebrafish metallothionein gene promoter in a zebrafish caudal fin cell-line, SJD. 1. Mar. Environ. Res. 2002, 54, 335-339. [CrossRef] [PubMed]

22. Kalaiselvi Sivalingam, N.N.; Seepoo, A.M.; Gani, T.; Selvam, S.; AzeezSait, S.H. Zebrafish fin-derived fibroblast cell line: A model for in vitro wound healing. J. Fish Dis. 2019, 42, 573-584. [CrossRef] [PubMed]

23. Yadav, K.; Lakra, W.S.; Sharma, J.; Goswami, M.; Singh, A. Development and characterization of a cell line TTCF from endangered mahseer Tor tor (Ham.). Fish Physiol. Biochem. 2012, 38, 1035-1045. [CrossRef] [PubMed]

24. Lakra, W.S.; Goswami, M. Development and characterization of a continuous cell line PSCF from Puntius sophore. J. Fish Biol. 2011, 78, 987-1001. [CrossRef]

25. Kumar, R.; Ravi, C.; Das, S.; Dharmaratnam, A.; Basheer, V.S.; Swaminathan, T.R. Establishment and characterization of a caudal fin-derived cell line, AOF, from the Oscar, Astronotus ocellatus. Fish Physiol. Biochem. 2019, 45, $123-131$. [CrossRef]

26. Lakra, W.S.; Goswami, M.; Yadav, K.; Gopalakrishnan, A.; Patiyal, R.S.; Singh, M. Development and characterization of two cell lines PDF and PDH from Puntius denisonii (Day 1865). In Vitro Cell. Dev. Biol. Anim. 2011, 47, 89-94. [CrossRef] [PubMed]

27. Kumar, A.; Godwin, J.W. Preparation and culture of limb blastema stem cells from regenerating larval and adult salamanders. Cold Spring Harb. Protoc. 2010, 2010, pdb-prot5367. [CrossRef]

28. Rosa, J.; Tiago, D.M.; Dias, J.; Cancela, M.L.; Laizé, V. Serum-specific stimulation of proliferation and mineralization of fish bone-derived cells. J. Appl. Ichthyol. 2010, 26, 251-256. [CrossRef]

29. Collodi, P.; Kamei, Y.; Ernst, T.; Miranda, C.; Buhler, D.R.; Barnes, D.W. Culture of cells from zebrafish (Brachydanio rerio) embryo and adult tissues. Cell Biol. Toxicol. 1992, 8, 43-61. [CrossRef]

30. Van Camp, J.K.; Beckers, S.; Zegers, D.; Van Hul, W. Wnt signaling and the control of human stem cell fate. Stem Cell Rev. 2014, 10, 207-229. [CrossRef]

31. Itoh, F.; Watabe, T.; Miyazono, K. Roles of TGF- $\beta$ family signals in the fate determination of pluripotent stem cells. Semin. Cell Dev. Biol. 2014, 32, 98-106. [CrossRef] 
32. Wang, L.; Schulz, T.C.; Sherrer, E.S.; Dauphin, D.S.; Shin, S.; Nelson, A.M.; Ware, C.B.; Zhan, M.; Song, C.Z.; Chen, X.; et al. Self-renewal of human embryonic stem cells requires insulin-like growth factor-1 receptor and ERBB2 receptor signaling. Blood 2007, 110, 4111-4119. [CrossRef] [PubMed]

33. Lotz, S.; Goderie, S.; Tokas, N.; Hirsch, S.E.; Ahmad, F.; Corneo, B.; Le, S.; Banerjee, A.; Kane, R.S.; Stern, J.H.; et al. Sustained levels of FGF2 maintain undifferentiated stem cell cultures with biweekly feeding. PLoS ONE 2013, 8, e56289. [CrossRef] [PubMed]

34. Pease, S.; Braghetta, P.; Gearing, D.; Grail, D.; Williams, R.L. Isolation of embryonic stem (ES) cells in media supplemented with recombinant leukemia inhibitory factor (LIF). Dev. Biol. 1990, 141, 344-352. [CrossRef]

35. Shibata, E.; Yokota, Y.; Horita, N.; Kudo, A.; Abe, G.; Kawakami, K.; Kawakami, A. Fgf signalling controls diverse aspects of fin regeneration. Development 2016, 143, 2920-2929. [CrossRef] [PubMed]

36. Lehrberg, J.; Gardiner, D.M. Regulation of axolotl (Ambystoma mexicanum) limb blastema cell proliferation by nerves and BMP2 in organotypic slice culture. PLoS ONE 2015, 10, e0123186. [CrossRef]

37. Suemori, H.; Nakatsuji, N. Establishment of the embryo-derived stem (ES) cell lines from mouse blastocysts: Effects of the feeder cell layer. Dev. Growth Differ. 1987, 29, 133-139. [CrossRef]

38. Adams, J.C.; Watt, F.M. Regulation of development and differentiation by the extracellular matrix. Development 1993, 117, 1183-1198.

39. Robertson, E.J. Embryo-derived stem cell lines. In Teratocarcinomas and Embryonic Stem Cells: A Practical Approach; Robertson, E.J., Ed.; IRL Press: Oxford, UK, 1987; pp. 71-112.

40. Saeinasab, M.; Matin, M.M.; Rassouli, F.B.; Bahrami, A.R. Blastema cells derived from New Zealand white rabbit's pinna carry stemness properties as shown by differentiation into insulin producing, neural, and osteogenic lineages representing three embryonic germ layers. Cytotechnology 2016, 68, 497-507. [CrossRef]

41. Andrews, P.W. Retinoic acid induces neuronal differentiation of a cloned human embryonal carcinoma cell line in vitro. Dev. Biol. 1984, 103, 285-293. [CrossRef]

42. Wakamatsu, Y.; Ozato, K.; Sasado, T. Establishment of a pluripotent cell line derived from a medaka (Oryzias latipes) blastula embryo. Mol. Mar. Biol. Biotechnol. 1994, 3, 185-191.

43. Parameswaran, V.; Laizé, V.; Gavaia, P.J.; Cancela, M.L. ESSA1 embryonic stem like cells from gilthead seabream: A new tool to study mesenchymal cell lineage differentiation in fish. Differentiation 2012, 84, 240-251. [CrossRef] [PubMed]

44. White, J.A.; Boffa, M.B.; Jones, B.; Petkovich, M. A zebrafish retinoic acid receptor expressed in the regenerating caudal fin. Development 1994, 120, 1861-1872. [PubMed]

45. Means, A.L.; Gudas, L.J. The roles of retinoids in vertebrate development. Annu. Rev. Biochem. 1995, 64, 201-233. [CrossRef] [PubMed]

46. Mongan, N.P.; Gudas, L.J. Diverse actions of retinoid receptors in cancer prevention and treatment. Differentiation 2007, 75, 853-870. [CrossRef] [PubMed]

47. Soprano, D.R.; Teets, B.W.; Soprano, K.J. Role of retinoic acid in the differentiation of embryonal carcinoma and embryonic stem cells. Vitam. Horm. 2007, 75, 69-95. [CrossRef] [PubMed]

48. Gudas, L.J.; Wagner, J.A. Retinoids regulate stem cell differentiation. J. Cell. Physiol. 2011, 226, 322-330. [CrossRef]

49. Gudas, L.J. Emerging roles for retinoids in regeneration and differentiation in normal and disease states. Biochim. Biophys. Acta 2012, 1821, 213-221. [CrossRef]

50. Mathew, L.K.; Sengupta, S.; Franzosa, J.A.; Perry, J.; La Du, J.; Andreasen, E.A.; Tanguay, R.L. Comparative expression profiling reveals an essential role for Raldh2 in epimorphic regeneration. J. Biol. Chem. 2009, 284, 33642-33653. [CrossRef]

51. Blum, N.; Begemann, G. Retinoic acid signaling controls the formation, proliferation and survival of the blastema during adult zebrafish fin regeneration. Development 2012, 139, 107-116. [CrossRef]

52. Géraudie, J.; Monnot, M.J.; Brulfert, A.; Ferretti, P. Caudal fin regeneration in wild type and long-fin mutant zebrafish is affected by retinoic acid. Int. J. Dev. Biol. 1995, 39, 373-381.

53. Cardeira, J.; Gavaia, P.J.; Fernández, I.; Cengiz, I.F.; Moreira-Silva, J.; Oliveira, J.M.; Reis, R.L.; Leonor Cancela, M.; Laizé, V. Quantitative assessment of the regenerative and mineralogenic performances of the zebrafish caudal fin. Sci. Rep. 2016, 6, 39191. [CrossRef] [PubMed]

54. Tighe, A.P.; Gudas, L.J. Retinoic acid inhibits leukemia inhibitory factor signaling pathways in mouse embryonic stem cells. J. Cell. Physiol. 2004, 198, 223-229. [CrossRef] [PubMed] 
55. Xing, J.G.; Lee, L.E.; Fan, L.; Collodi, P.; Holt, S.E.; Bols, N.C. Initiation of a zebrafish blastula cell line on rainbow trout stromal cells and subsequent development under feeder-free conditions into a cell line, ZEB2J. Zebrafish 2008, 5, 49-63. [CrossRef] [PubMed]

56. Robles, V.; Marti, M.; Izpisua Belmonte, J.C. Study of pluripotency markers in zebrafish embryos and transient embryonic stem cell cultures. Zebrafish 2011, 8, 57-63. [CrossRef]

57. Simes, D.C.; Williamson, M.K.; Schaff, B.J.; Gavaia, P.J.; Ingleton, P.M.; Price, P.A.; Cancela, M.L. Characterization of osteocalcin (BGP) and matrix gla protein (MGP) fish specific antibodies: Validation for immunodetection studies in lower vertebrates. Calcif. Tissue Int. 2004, 74, 170-180. [CrossRef]

(C) 2020 by the authors. Licensee MDPI, Basel, Switzerland. This article is an open access article distributed under the terms and conditions of the Creative Commons Attribution (CC BY) license (http://creativecommons.org/licenses/by/4.0/). 